\title{
Identifying Heating Technologies suitable for Historic Churches, Taking into Account Heating Strategy and Conservation through Pairwise Analysis
}

\author{
Robin Talbot $^{1 *}$, Arman Hashemi ${ }^{2}$, Philip Ashton ${ }^{1}$ and Marco Picco ${ }^{1}$ \\ ${ }^{1}$ University of Brighton, School of Environment and Technology, Lewes Road, Brighton, BN2 4AT \\ ${ }^{2}$ University of East London, School of Architecture, Computing and Engineering, Docklands Campus, London, E15 2RD
}

\begin{abstract}
As a result of difficulty meeting energy efficiency through fabric alteration, historic churches must focus on heating systems and operational strategy as key to reducing carbon emissions. Strategies can be defined as local or central heating. Local heating strives to heat occupants, while central heating aims to heat the building fabric and therefore the occupants. Each strategy requires a different approach to control and technology in response to priorities such as conservation, comfort and cost. This paper reviews current and emerging technologies in the context of church heating. The fuel source, heat generation technology and heat emitter are arranged in a matrix, with pairwise analysis undertaken to create weightings for each assessment criteria. The process of constructing the matrix and undertaking pairwise analysis using personas is discussed. The result is a ranking of fuels and technologies appropriate to the main priorities and individual preferences. Some desirable technologies are inherently more damaging to historic church environments due to invasive installation. These technologies score poorly when the aim is fabric preservation. Greener fuels, like biomass, may rank lower than fossil fuels, due in part to operational differences.
\end{abstract}

\section{Introduction}

With a design life of 20 to 30 years space heating systems represent a significant investment for the building owner and operator [1]. Designed to condition indoor spaces for human habitation, modern heating systems utilise various technologies to achieve control over the intensity and duration of heating events. In the UK almost half of final energy consumed is to provide heat. Most of this heat energy comes from burning natural gas, with the remainder made up of electric, oil, liquified petroleum gas (LPG), solid fuel, bioenergy and waste [2].

Historic churches were built without heating systems. Changes to the building size and fabric have occurred in response to changing styles, leadership and technological advances over the lifetime of the building. The ecclesiastical sector responded to change by heating churches using early forms of freestanding stoves fired by solid fuels, such as the Tortoise stove developed in the 1830s [3]. Heating boilers were manufactured in quantity from 1860s onward, with radiators introduced in the 1880s [4]. Eventually hydronic systems were installed, giving a heating system that could extend to all areas of the building. However, currently there are differing opinions on the validity of heating the building fabric. Many artefacts had already been present in the unheated building for many generations and survived without requiring ongoing conservation. Yet there is some evidence that the introduction of heating systems and striving to meet human comfort levels created problems for the building fabric and its contents $[5,6]$. This leads to the theory that the building needs no heat input to function properly and could be left to establish its own microclimates [7], able to passively control fluctuations in temperature and relative humidity using structure and geometry [8]. Conversely, the idea that the building benefits from regular or sustained low level heat input is also present amongst researchers and the ecclesiastical heating industry $[9,10]$. This division of opinions can lead to different solutions to the common concern of making the church building warm and welcoming to anyone who chooses to attend. There is growing awareness of the large amounts of energy required to heat the building fabric to the level of human comfort. This energy is excessive in both the cost burden and the associated greenhouse gas emissions [11].

Three main strategies currently exist for space heating in historic churches: 1) rapid increase in air temperature for short periods, 2) low temperature heating over extended periods, with an increase in temperature during services as required, and 3) radiant heating for occupants where there is no direct fabric heating. Each strategy requires a different approach to control and

\footnotetext{
* Corresponding author: r.talbot@brighton.ac.uk
} 
technology in response to priorities such as conservation, comfort and cost. These strategies could be further refined to control mechanisms: local heating or central heating. Central heating is designed to create uniform conditions in the building, which often entails large energy consumption. Local heating strives to provide heat to occupants in specific areas of the building using suitable intermittent heating systems, often radiant heating [12].

The strategy adopted hinges upon factors which must be taken into account when choosing an appropriate heating system. These factors are client specific but are defined as cost, comfort, control and convenience [13]. Additional factors defined by Aste (2017) must be considered in the context of a historic church: occupant satisfaction, conservation of fabric and artefacts, and energy use [14]. It is noted that central heating systems in churches are often inadequate in providing comfort for occupants and fail to get low grade heat into the building fabric [15]. Long preheat times are required to heat the volume of air contained within many churches $[16,17]$. Much of the heat that is provided rises in the large volume space and is therefore of little benefit to those at floor level [12].

Taking into consideration these constraints, strategies and design factors this paper looks at a method for assessing fuels and space heat technologies, both current and emerging, in the context of a historic church setting.

\section{Research methodology}

This research reviews the current state of the art, both in church heating and the wider field of heating technologies available on the market. In addition, where possible, emerging technologies are also considered and discussed in the research. Gathering information on available space heating products and fuel sources began through a literature review of scientific papers and case study examples. While the case studies were not always detailed in a way that suited further analysis, they indicate the type of systems being chosen in real world situations. Additional information was gathered through a trade show in March of 2020, where manufacturers and suppliers were promoting existing and new products for the market.

Fuels, heat generation units and emitter options have been grouped and entered into a matrix. No predetermination is made on the suitability of fuels or technologies at this stage; all types of fuel and technology are included. Each item entered into the matrix receives a score using up to seven criteria defined by the author. Due to some criteria being subjective, weightings are produced through pairwise analysis, which allows the various criteria to be assessed against each other. Abel et al (2018) define pairwise analysis as decomposition of a larger decision problem into more manageable smaller chunks, facilitating separation of concerns that ensures an accurate extraction of the preferences of a decision maker [18]. The resulting weights are applied to the matrix. The development of five personas has been undertaken to represent an individual's motivation for certain outcomes e.g. sustainability, control, conservation etc.

\section{Defining criteria}

Rather than first defining the strategy it was felt appropriate to assess all technologies equally using the same criteria. This falls in line with advice from CIBSE to create a ranking and weighted matrix to assess suitability [13]. The assessment criteria were drawn from the advice contained within How to design a heating system. CIBSE Knowledge Series: KS8. However, the topic of comfort was largely excluded at this stage of the research. This decision was made to avoid bias in the results, where certain systems would gain an advantage due to perceived or actual comfort attained. The design of a comparison matrix needed to achieve comparison of fuel, heat generation unit and heat emitter under a unified range of criteria. When assessing fuel and heat generation unit it was evident that carbon intensity and efficiency could be evaluated in the matrix using one column or unified criteria. For heat emitters this criteria was not applicable, given the emitter's function is to release the energy, therefore this column/criteria was not utilised. An explanation of each criteria is provided below with criteria separated into two categories in Table 1.

Control: How controllable is the fuel, heat production and delivery of heat? Is control a priority? Can the heat output to the space be controlled effectively or even locally?

Practicality for church setting: This is a recognition that certain technologies may be unsuitable in the church context. I.e. there is no space or scope for large plant rooms with buffer tanks or fuel storage. The system's operation does not match the usage pattern of the church.

Installation cost: Installation cost is a key consideration in making changes.

Ease of delivery: Covers all aspects from delivering the fuel, delivering energy to the heat emitters. E.g. woodchip and pellets can be delivered to the boiler by automation but the fuel needs delivered to site. Pipework in comparison to electric power cable.

Maintenance cost: Has serious implications for running the system. Maintenance cycles for some equipment types are more regular than others. Do you have to use a specialist to service the heating?

Aesthetic value: Will this aspect of the heating system look out of place in a church setting? Is it important that heating systems should look right in the church?

Carbon intensity (efficiency for heat generation device): Each fuel has an associated carbon intensity. Is the carbon intensity a priority over other factors? (Is high efficiency a priority?).

Table 1. Criteria utilised in the assessment matrix. 


\begin{tabular}{|c|c|}
\hline $\begin{array}{c}\text { Typical criteria for } \\
\text { heating system } \\
\text { selection/components }\end{array}$ & $\begin{array}{c}\text { Specific criteria for } \\
\text { historic church }\end{array}$ \\
\hline Control & $\begin{array}{c}\text { Practicality for } \\
\text { church setting }\end{array}$ \\
\hline Installation cost & Ease of delivery \\
\hline Maintenance cost & Aesthetic value \\
\hline Carbon intensity/Efficiency & \\
\hline
\end{tabular}

It could be argued that 'Ease of delivery' and 'Practicality for church setting' are very similar criteria and should be merged to limit duplication or variation on a similar theme. These two categories have been chosen to reflect the difference between the overall site the church inhabits and that of the internal space. Fuels are delivered to site by various means and may have an impact upon the exterior appearance or fabric of the church. Heat emitters are contained within the building and require some infrastructure to transport the energy from the fuel or heat generation unit through to the emitter. If greater simplicity in the matrix is required it is possible to alter criteria to serve both purposes.

\subsection{Creating weightings}

In order to assess each technology a score was given in each criteria. A simple 1-5 Likert scale was used [19], with one being the lowest score (least suited to the stipulated criteria) and five being the highest (most suited to the criteria). The matrix has been colour coded for ease of viewing scoring. Using this design for the matrix matched many other matrices common in various industries. Risk assessment can be carried out using coloured cells and/or number selection [20] and many assessment tables use colours for ease of comparing options side by side [21].

Scores were based upon reference material and technical information available from manufactures. Table 3 gives an explanation of the method used to score each item in each category. A completed matrix is included in the appendix to illustrate scores attributed to each technology. Several of the chosen criteria are highly subjective, therefore a method was sought to add weightings to the matrix when assessing each criteria against another. A weighted decision matrix using pairwise analysis to generated appropriate weightings from the allocated scores was therefore necessary [19, 22].

\subsection{Pairwise analysis}

Pairwise analysis is carried out using a comparison table designing to compare each item against another criteria. The design of the table and the formula for calculating the weightings was derived from Salustri (2020) [22]. Duplicate cells in the table are blocked out to avoid the same criteria being compared more than once. Working from left to right each item is assessed against each column heading. Equal importance can be given to criteria if desired by placing both letters in the cell. An example is provided in Table 2. Totals at the foot of columns represent the number of times the letter/criteria appears in not just one column but the whole table of responses. Associated calculations to find the weightings for each criteria are provided below.

Table 2. Completed pairwise table with author's responses.

\begin{tabular}{|c|c|c|c|c|c|c|c|c|}
\hline $\begin{array}{l}\text { Author's } \\
\text { responses }\end{array}$ & & A & B & C & $\mathrm{D}$ & $\mathrm{E}$ & $\mathrm{F}$ & $\mathrm{G}$ \\
\hline Ease of delivery & A & - & $\mathrm{B}$ & $\begin{array}{l}\text { A } \\
\text { C }\end{array}$ & $\begin{array}{l}\text { A } \\
\text { D }\end{array}$ & $\mathrm{E}$ & $\begin{array}{l}\text { A } \\
\text { F }\end{array}$ & G \\
\hline Installation cost & $\mathrm{B}$ & - & - & $\begin{array}{l}\mathrm{B} \\
\mathrm{C}\end{array}$ & $\mathrm{B}$ & $\begin{array}{l}B \\
E\end{array}$ & $\begin{array}{l}\mathrm{B} \\
\mathrm{F}\end{array}$ & $\mathrm{B}$ \\
\hline Maintenance cost & $\mathrm{C}$ & - & - & - & $\mathrm{C}$ & $\begin{array}{l}\mathrm{C} \\
\mathrm{E}\end{array}$ & $\begin{array}{l}\mathrm{C} \\
\mathrm{F} \\
\end{array}$ & $\mathrm{C}$ \\
\hline Aesthetic value & $\mathrm{D}$ & - & - & - & - & $\mathrm{E}$ & $\mathrm{F}$ & $\begin{array}{l}E \\
G\end{array}$ \\
\hline Control & $\mathrm{E}$ & - & - & - & - & - & $\begin{array}{l}\mathrm{E} \\
\mathrm{F} \\
\end{array}$ & $\mathrm{E}$ \\
\hline $\begin{array}{l}\text { Practicality for } \\
\text { church setting }\end{array}$ & $\mathrm{F}$ & - & - & - & - & - & - & $\begin{array}{l}\mathrm{F} \\
\mathrm{G}\end{array}$ \\
\hline Carbon intensity & $\mathrm{G}$ & - & - & - & - & - & - & - \\
\hline Totals & & 3 & 6 & 5 & 1 & 7 & 6 & 3 \\
\hline
\end{tabular}

$X$ (weighting applied to each criteria) is calculated using the following formula. $X$ can be rounded to five decimal places without an error occurring in the final totals.

$$
\begin{gathered}
100=31 x \\
x=\frac{100}{31} \\
x=3.22581
\end{gathered}
$$$$
100=3 x+6 x+5 x+1 x+7 x+6 x+3 x
$$

$X$ is multiplied by the total occurrences from the pairwise chart. In Table 4 the criteria have been sorted by number of occurrences, therefore highest calculated weightings to least. The sum of all weightings must add up to 100. For heat emitters, which has one less criteria, Carbon intensity was excluded and the calculation adjusted for six rather than seven criteria.

The weights are added into the technology assessment matrix, with each criteria calculated according to the allocated score. The scoring and ranking of technologies is personalised to the individual who undertook the pairwise comparison exercise. Therefore, an individual who values conservation of the historic church environment may produce different scoring and ranking of technologies from an individual who values low carbon technologies. 


\begin{tabular}{|c|c|c|c|c|c|}
\hline $\begin{array}{l}\text { Explanation of } \\
\text { scoring for } \\
\text { each criteria. }\end{array}$ & 1 & 2 & 3 & 4 & 5 \\
\hline Control & $\begin{array}{l}\text { No control } \\
\text { over operation/ } \\
\text { response }\end{array}$ & $\begin{array}{l}\text { Limited control } \\
\text { over operation/ } \\
\text { response }\end{array}$ & $\begin{array}{c}\text { Slower response to } \\
\text { heat demand }\end{array}$ & $\begin{array}{l}\text { Medium response } \\
\text { to head demand }\end{array}$ & $\begin{array}{l}\text { Fast response to heat } \\
\text { demand }\end{array}$ \\
\hline $\begin{array}{c}\text { Installation } \\
\text { cost }\end{array}$ & High & High-medium & Medium & Medium-low & Low \\
\hline $\begin{array}{l}\text { Practicality } \\
\text { for church } \\
\text { setting }\end{array}$ & $\begin{array}{l}\text { Equipment } \\
\text { design not } \\
\text { suited to } \\
\text { church setting }\end{array}$ & $\begin{array}{l}\text { Mismatch of } \\
\text { performance and } \\
\text { no space for plant } \\
\text { room equipment }\end{array}$ & $\begin{array}{c}\text { Mismatch of } \\
\text { performance and } \\
\text { limited space for } \\
\text { plant room } \\
\text { equipment }\end{array}$ & $\begin{array}{l}\text { Partially suited to } \\
\text { usage pattern and } \\
\text { plant room space }\end{array}$ & $\begin{array}{l}\text { Performance suited to } \\
\text { usage and space for } \\
\text { plant room equipment }\end{array}$ \\
\hline $\begin{array}{l}\text { Maintenance } \\
\text { cost }\end{array}$ & $\begin{array}{l}\text { High cost via } \\
\text { specialist }\end{array}$ & $\begin{array}{l}\text { Medium cost less } \\
\text { specialised }\end{array}$ & $\begin{array}{c}\text { Medium cost } \\
\text { wider availability }\end{array}$ & $\begin{array}{c}\text { Medium to low } \\
\text { cost wide } \\
\text { availability }\end{array}$ & $\begin{array}{l}\text { Widely available and } \\
\text { lower cost }\end{array}$ \\
\hline $\begin{array}{c}\text { Ease of } \\
\text { delivery } \\
\text { (Emitters) }\end{array}$ & $\begin{array}{l}\text { No access to } \\
\text { site. Manual } \\
\text { handling } \\
\text { required (heat } \\
\text { delivery } \\
\text { complex and } \\
\text { poor) }\end{array}$ & $\begin{array}{l}\text { Limited access to } \\
\text { site. New } \\
\text { infrastructure } \\
\text { required (heat } \\
\text { delivery less } \\
\text { effective) }\end{array}$ & $\begin{array}{l}\text { Access to site for } \\
\text { delivery to a } \\
\text { storage vessel } \\
\text { (location } \\
\text { dependant heating } \\
\text { effect) }\end{array}$ & $\begin{array}{l}\text { Fuel delivered to } \\
\text { site, heat } \\
\text { transferred via } \\
\text { existing pipework } \\
\text { (emitter placed } \\
\text { where heat } \\
\text { required) }\end{array}$ & $\begin{array}{c}\text { Fuel delivery } \\
\text { automated to site via } \\
\text { pipe/cable. Minimal } \\
\text { impact to transfer heat } \\
\text { to emitters (minimal } \\
\text { impact to place } \\
\text { emitter where } \\
\text { required) }\end{array}$ \\
\hline $\begin{array}{l}\text { Aesthetic } \\
\text { value }\end{array}$ & $\begin{array}{l}\text { Inappropriate } \\
\text { in this setting }\end{array}$ & Limited appeal & $\begin{array}{l}\text { Acceptable or can } \\
\text { be made to fit }\end{array}$ & $\begin{array}{l}\text { Appropriate and } \\
\text { accepted in full } \\
\text { view } \\
\end{array}$ & $\begin{array}{c}\text { Can be hidden from } \\
\text { sight or design highly } \\
\text { appropriate }\end{array}$ \\
\hline $\begin{array}{l}\text { Carbon } \\
\text { intensity }\end{array}$ & $>0.4$ & $0.4-0.3$ & $0.3-0.185$ & $0.185-0.17$ & Lower than 0.17 \\
\hline Efficiency & $<60 \%$ & $60-70 \%$ & $70-80 \%$ & Up to $100 \%$ & Above $100 \%$ \\
\hline
\end{tabular}

Table 4. Ranked criteria with associated weightings.

\begin{tabular}{|l|r|r|r|}
\hline Criteria & & $\begin{array}{r}\text { Number of } \\
\text { occurrences } \\
\text { in table }\end{array}$ & $\begin{array}{r}\text { Occurrences } \\
* X \\
(3.22581)\end{array}$ \\
\hline Control & $\mathrm{E}$ & 7 & 22.58065 \\
\hline $\begin{array}{l}\text { Installation } \\
\text { cost }\end{array}$ & $\mathrm{B}$ & 6 & 19.35484 \\
\hline $\begin{array}{l}\text { Practicality } \\
\text { for church } \\
\text { setting }\end{array}$ & $\mathrm{F}$ & 6 & 19.35484 \\
\hline $\begin{array}{l}\text { Maintenance } \\
\text { cost }\end{array}$ & $\mathrm{C}$ & 5 & 16.12903 \\
\hline $\begin{array}{l}\text { Ease of } \\
\text { delivery }\end{array}$ & $\mathrm{A}$ & 3 & 9.677419 \\
\hline $\begin{array}{l}\text { Carbon } \\
\text { intensity }\end{array}$ & $\mathrm{G}$ & 3 & 9.677419 \\
\hline $\begin{array}{l}\text { Aesthetic } \\
\text { value }\end{array}$ & $\mathrm{D}$ & 1 & 3.225806 \\
\hline \multicolumn{2}{|r|}{} & $\mathrm{Sum}$ & 100 \\
\cline { 3 - 4 }
\end{tabular}

\subsection{Creation of personas}

The concept of using personas was motivated by the often conflicting criteria presented by historic churches. Personas are utilised in product design settings to better understand the eventual user of the product [23]. Long (2009), during research to determine if the use of personas generated more user-friendly solutions, found that the student group involved in the research were more enthused and produced higher quality results in response to understanding the end user. Other outcomes highlighted were the improvement in communication between teams and constructive design discussions with greater focus on the user. Using personas was likely to give clearer focus at the outset of the research and ideas stages [24].

Planning and decisions on appropriate heating systems may pass through several church committees before approval, therefore one person's view of appropriate technology and strategy may differ significantly from another in the overseeing committee.

Personas were created without resorting to stereotypes. It is recognised that those employed and working voluntarily for the church have varied backgrounds and employment experience.

Five personas have been created for this study:

A. Environmental enthusiast who values sustainable practices

B. Heritage focus with significant interest in preserving locally important artefacts

C. Interest in art and religious artworks

D. Local resident who wishes increased community access to the church in the future

E. Engineer with an interest in music, strives to maintain status quo 
Table 5. Ranking of criteria by each persona with subjective criteria highlighted.

\begin{tabular}{|c|c|c|c|c|c|}
\hline Ranking & Persona A & Persona B & Persona C & Persona D & Persona E \\
\hline 1 & $\begin{array}{l}\text { Installation } \\
\text { cost }\end{array}$ & $\begin{array}{c}\text { Installation } \\
\text { cost }\end{array}$ & $\begin{array}{l}\text { Practicality } \\
\text { for church } \\
\text { setting }\end{array}$ & $\begin{array}{l}\text { Practicality } \\
\text { for church } \\
\text { setting }\end{array}$ & $\begin{array}{c}\text { Installation } \\
\text { cost }\end{array}$ \\
\hline 2 & $\begin{array}{l}\text { Carbon } \\
\text { intensity }\end{array}$ & $\begin{array}{l}\text { Practicality } \\
\text { for church } \\
\text { setting }\end{array}$ & $\begin{array}{c}\text { Aesthetic } \\
\text { value }\end{array}$ & Carbon & Control \\
\hline 3 & Control & $\begin{array}{l}\text { Aesthetic } \\
\text { value }\end{array}$ & Control & $\begin{array}{l}\text { Ease of } \\
\text { delivery }\end{array}$ & $\begin{array}{l}\text { Maintenance } \\
\text { cost }\end{array}$ \\
\hline 4 & $\begin{array}{l}\text { Practicality } \\
\text { for church } \\
\text { setting }\end{array}$ & Control & $\begin{array}{l}\text { Carbon } \\
\text { intensity }\end{array}$ & $\begin{array}{l}\text { Maintenance } \\
\text { cost }\end{array}$ & $\begin{array}{l}\text { Practicality } \\
\text { for church } \\
\text { setting }\end{array}$ \\
\hline 5 & $\begin{array}{l}\text { Ease of } \\
\text { delivery }\end{array}$ & $\begin{array}{l}\text { Maintenance } \\
\text { cost }\end{array}$ & $\begin{array}{l}\text { Installation } \\
\text { cost }\end{array}$ & Control & $\begin{array}{l}\text { Aesthetic } \\
\text { value }\end{array}$ \\
\hline 6 & $\begin{array}{l}\text { Maintenance } \\
\text { cost }\end{array}$ & $\begin{array}{l}\text { Ease of } \\
\text { delivery }\end{array}$ & $\begin{array}{l}\text { Ease of } \\
\text { delivery }\end{array}$ & $\begin{array}{l}\text { Aesthetic } \\
\text { value }\end{array}$ & $\begin{array}{l}\text { Ease of } \\
\text { delivery }\end{array}$ \\
\hline 7 & $\begin{array}{l}\text { Aesthetic } \\
\text { value }\end{array}$ & $\begin{array}{l}\text { Carbon } \\
\text { intensity }\end{array}$ & $\begin{array}{l}\text { Maintenance } \\
\text { cost }\end{array}$ & $\begin{array}{c}\text { Installation } \\
\text { cost }\end{array}$ & $\begin{array}{l}\text { Carbon } \\
\text { intensity }\end{array}$ \\
\hline
\end{tabular}

Using each persona's information in the pairwise analysis it was possible to rank the individual preferences for most important criteria, see Table 5. The rankings reveal the different priorities placed upon the heating design process. Some personas are more influenced by subjective criteria, which should not be deemed superfluous as these are of greater importance to the individual.

Weightings were created from the pairwise analysis and applied to the technology scoring matrix. Each persona generated different rankings for the individual fuel and technologies. The results reveal the dominant fuels and technologies that may be more suited for church heating. It appears carbon intensity plays an important role in the ranking of fuels. Although wood fuels unfortunately do not score well in the matrix. This is due to the difficulty in using these energy sources in many church settings.

Despite the suitability of underfloor heating for the church environment it remains at the bottom of the ranking due to the invasive installation process and associated high cost. The alternative of a floating false floor scored much higher and it can accommodate various heating system types without removing the existing floor of the church. Radiators, which are widely accepted heating furniture in churches, rank well in the matrix. They are suited to many church operation schedules and when coupled to a suitable energy source can provide successful heating. Fan coils, which are also common additions in churches, do not rank highly here. It should be noted that this term covers many different styles of fan coil and it should not be routinely discounted without further investigation. Certain designs can be completely hidden and have quiet running fans, limiting the visual and noise impact upon the historic church environment.

\section{Discussion}

Characteristics and specificities of single churches and associated artefacts are not taken into account in this work, as the aim of the work is general guidance rather than final choice. The next step should be to investigate suitability in consultation with technical data on systems and materials. This review set out to assess technologies suited to space heating in historic churches. Firstly, data was gathered on current and emerging technologies which are used or could be applied in this context. A matrix was created to score fuel, heat generation and heat emitter according to suitability. Some criteria were considered subjective, therefore weightings were created using pairwise analysis to reduce the impact and reflect the preference of individual criteria for heating system performance. Personas were created to reflect typical individual interest areas, with the expectation that the heating design process would be improved by assessing interaction with the matrix. Finally, the outcome of the author's assessment of technologies was presented with suggested suitability of technology. These tasks and outcomes will now be discussed in the following text.

\subsection{Using the matrix}

The outcome of the weighted matrix for one persona (persona D) is outlined in the following example. The weightings generated from the pairwise task resulted in natural gas, BioLPG and electricity becoming the top three fuel choices. Air or water source heat pumps topped the ranking of heat generators, with gas, electric and oil boilers in third to fifth place respectively. In terms of emitter type, heated cushions/mats were the highest ranked technology (this was the same for all personas), however gas powered radiant heaters were 
significantly higher in Persona D ranking when compared to other personas. Tube heaters and radiators were allocated $3^{\text {rd }}$ and $4^{\text {th }}$ position in the ranking. Radiant panels did not rank highly for Persona D, despite their suitability for many churches. This was the lowest ranking for radiant panels among the personas used.

The use of a 1-5 Likert scale did create one disadvantage when scoring low carbon and renewable technologies. Due to the range of efficiencies presented by the various technologies only one score was available for heat generation units achieving in excess of $100 \%$. This could perhaps be altered to allow a separate score for $100-200 \%$ and those $200 \%+$ technologies. This would assist in differentiating between those generation units that only just outperform a condensing gas boiler and those that substantially exceed them in efficiency terms. It was felt, in this case, that the technologies reviewed here required the use of all five categories to represent the range of efficiencies.

The matrix does not fully take into account the heating systems function and response times at this stage. This is a deliberate attempt to avoid prejudicing the result with preconceived ideas on which system would be suitable for churches. If the proposal were for a fast responsive heating system to be used a few times a week then a gas fired radiator system may automatically be specified for the task. However, the matrix starts with the selection of criteria rather than beginning to design the system according to the task. This appears to be in line with the principles of product design, where the user is first identified or defined. Individual interests are taken into account and it is these areas that chiefly focus the design task on what they want rather than what is feasible to give them, a criticism which could be said of the heating design process. It is important to note that if persona details and goals are not clear and correct inappropriate designs may result [24].

There appeared a tendency in the matrix to highly rank certain fuels, heat generation units and emitters, despite changes in the weightings from each persona. This appears to be a result of the original scoring attributed to the technology. Some are inherently more suited to the church environment and the scoring reflects this, resulting in consistent high placing in the output ranking. Heated cushions came first in the ranking for all personas. However, it could be argued that this occurrence allows alternative methods of heat provision to be successfully presented in the design process, prompting the user of the matrix to consider if their strategy is appropriate and compatible with the technology they may favour. Inconsistency within pairwise comparison when used for more than a few elements is almost inevitable [18]. Pairwise comparison is complex as a result of the many comparisons required, therefore it is difficult for individuals with lack of experience in data analysis [25]. It was found in this study that some individuals did not understand how to complete the pairwise comparison table, either not undertaking the task or altering the table to suit their understanding of the task. Some additional guidance or alteration of the presentation of the table may assist understanding the mode of operation when comparing multiple criteria against one another.

It is hoped that the pairwise comparison task and interaction with the personised matrix will allow those considering heating system technology to understand the compromises that may be required, in order to achieve their most important criteria, be that occupant comfort or conservation etc.

\subsection{Data gathering on heating strategies}

The two opposing strategies existing for heating historic churches are: no heating or heating often. This review does not attempt to cover occupant comfort in any great detail, despite its relevance to heating selection, as it will be researched and discussed in later work. Constant heating is only required in building with permanent occupation. Additionally, heating buildings on a constant cycle causes increased air movements and temperature differences which cause faster soiling of objects and fabric. Static heaters and radiators often blacken nearby surfaces and walls [26]. Heating a church daily would result in large fluctuations in relative humidity, potentially damaging artefacts, art work and wooden items [27].

The use of manufacturer's data and case studies emerged as the most appropriate source of information for this review. Scientific journal publications could have been used in addition to manufacture's data, however these were often dealing with the application of the technology in a specific setting as opposed to the merits of the technology. Journal papers do not feature strongly in this review, thus avoiding pre-empting the technologies suitable for the task of church heating. The approach taken allows all investigated fuel sources and technologies to be entered into the study, even when individuals have reservations on the suitability, perhaps from their experience, of certain systems by the demands of a historic church.

\subsection{Suitable heating technologies}

The output of the matrix allows a clear indication of heat generation units that would be viewed as unusual choices in a church building. The more niche heat generator types receive a low ranking in the matrix. Air source heat pumps and hydrogen boilers were the highest ranking zero to low carbon technologies in the matrix, appearing as high as $3^{\text {rd }}$ for some personas. Boiler systems appear to dominate the top of the ranked heat generation technologies. This perhaps reflects the current technology in place in many churches. A new boiler could easily be integrated into the existing system without undertaking a major overhaul.

The least invasive technologies rank highly in the table of heat emitters. Heated cushions do not impact the 
historic church setting and score well here as they are easy to install and provide local heat to the occupant. They do not heat the volume of air or the fabric of the church, this leads to vastly different internal temperatures than most occupants currently expect indoors. Comfort was not fully assessed in the matrix, therefore it remains a step to consider at a later stage in the heating design process and will be addressed as part of the overall research project.

Lodi (2017) states that many retrofit solutions are not compatible with historic buildings, with the additional dimension of requiring non-invasive approaches. There are only a few options which can enhance comfort while achieving energy saving and conservation goals [28]. One of these options may be radiant heating systems. Radiant heaters generally fell in the middle of the ranking of heat emitters for most personas. These heaters do not directly heat the air volume of the building, therefore the air temperature inside the church may be low. Radiant heaters, both gas fuelled and electric, have featured in churches for a significant length of time, although their popularity seems to vary. Some churches are eager to remove them for replacement with central heating, while other churches are striving to do the opposite.

Striving to heat only the occupant results in reduced air movement within the building [29], which can be beneficial for comfort and reduce deposition of dust and particulates on sensitive items. Infrared heaters are best suited to a conservation first approach in small churches with intermittent usage patterns [12]. In larger open space there may be limited areas available to mount heaters overhead. Infrared systems can be effectively coupled with other systems to manage the moisture content of the building. Many churches in the UK suffer from dampness, not dryness [30], with Semprini (2017) suggesting an additional air handling system for relative humidity control may be appropriate when using infrared systems [31]. This type of approach fits well with other advice that permanent heating will cause ongoing air movements and temperature differences that generate soiling on objects and walls in addition to conservation problems. Essentially the building and objects do not need heating, however heating has the benefit of controlling the moisture present in the building [32].

While the matrix does not provide the final answer for technology choice and strategy, it does prevent the deliberate disqualification of systems that are perceived as unsuitable for the historic church environment. It is not possible in this review of technologies to cover all positive and negatives from each type of system. Future publication will expand upon the technologies reviewed as part of this study. Several technologies are proposed for further analysis despite their poor performance in the matrix. This is because they are examples of viable fuel and technology that can be utilised for church heating. For example, a biomass boiler is the obvious choice where there is a strong preference for wood as the energy source. Looking at heat emitters, fan coils and underfloor heating have been proposed, despite not ranking in the top six. These technologies have desirable qualities that cannot be overlooked. The matrix does however correctly highlight the complexity in using these technologies in the context of church heating, either on cost or practical terms.

\section{Conclusion}

The creation of a weighted matrix to assess fuels and technologies has been successfully demonstrated. The chosen criteria were suitable to rank technology according to allocated scores and persona derived weightings. The use of personas assisted in guiding the process towards user defined parameters rather than predetermined systems that traditionally fit the context of a historic church. The complex nature of pairwise analysis is perhaps a barrier to adoption of this type of approach for those not used to data analysis. A selection of fuels, heat generation units and emitters has been suggested as suitable for the church context, despite some scoring poorly in the matrix. Adjustments to the matrix may be necessary to ensure the user is not provided with results out of line with their preferences. Overall, the matrix has facilitated the creation of information and data which can assist the heating design process, giving it greater focus and partly removing predetermined outcomes. The matrix appears to allow alternative technologies to be better represented in the design process if the criteria weightings are correctly established.

This research forms part of a PhD study at the University of Brighton. This Science and Engineering in Arts Heritage and Archaeology (SEAHA) study is funded by the Engineering and Physical Sciences Research Council (EPSRC) and is a collaboration between University College London, University of Oxford and University of Brighton.

\section{References}

1. Historic England, B.S.E.T., Building Services Engineering and the Historic Environment - Oneday Course. 2019.

2. Office of Gas and Electricity Markets (ofgem) The Decarbonisation of Heat. 2016.

3. Geograph. Portway Tortoise Stove, St Thomas a Becket church, Brightling. 2021 15/01/2021]; Available from: https://www.geograph.org.uk/photo/2841311.

4. English Heritage Heating and Ventilation in Historic Building Engrineering Systems and Equipment, B. Roberts, Editor. 2008.

5. Legner, M. and M. Geijer. Heating regimes in old Swedish churches, c. 1880-1980. in 2nd European Workshop on Cultural Heritage Preservation. 
2012. Kjeller, Norway: Norwegian Institute for Air Research.

6. Makrodimitri, M., et al., Heating historic structures. A review of heating systems in historic church buildings and implications related to conservation and comfort. The case of four historic churches in Cambridge. 2017, Research Gate.

7. Camuffo, D., et al., An advanced church heating system favourable to artworks: A contribution to European standardisation. Journal of Cultural Heritage, 2010. 11(2): p. 205-219.

8. Broström, T., et al. Evaluation of different approaches of microclimate control in cultural heritage buildings. in Climate for CollectionsStandards and Uncertainties. Postprints of the Munich Climate Conference 7 to 9 November 2012. 2013.

9. Lawson-Smith, P., Environmental Control in Historic Buildings. Journal of Architectural Conservation, 1998. 4(1): p. 42-55.

10. Church EcoMiser 100\% efficient electric heating for churches. 2020 31/08/2020]; Available from: https://www.dunphychurchheating.co.uk/fuelinstallation/propane-heating/.

11. Church Care Review of heating guidance: Establishing principles, T.C.o. England, Editor. 2020.

12. Camuffo, D. and A. Della Valle, Church Heating: A Balance between Conservation and Thermal Comfort, in Experts' Roundtable on Sustainable Climate Managment Strategies. 2007, The Getty Conservation Institute: Tenerife, Spain.

13. Race, G.L. and H. Carwardine, How to design a heating system. 2006, London: CIBSE.

14. Aste, N., et al., CFD Comfort Analysis of a Sustainable Solution for Church Heating. 8th International Conference on Applied Energy (Icae2016), 2017. 105: p. 2797-2802.

15. Johnson, G. Heat pumps and churches - some points to bear in mind. [cited 2018 20/08/2018]; Available from: https://cofeportsmouth.contentfiles.net/media/assets /file/Heat Pumps and Churches.pdf.

16. Historic Scotland Refurbishment Case Study 19. Trial Church Heating: Radiant Panels and Air Source Heat Pump at Kilmelford Church. 2015, Historic Scotland.

17. Turcanu, F.E., M. Verdes, and I. Serbanoiu, Churches Heating: The Optimum Balance Between Cost Management and Thermal Comfort. 9th International Conference Interdisciplinarity in Engineering, Inter-Eng 2015, 2016. 22: p. 821-828.

18. Abel, E., L. Mikhailov, and J. Keane, Inconsistency reduction in decision making via multi-objective optimisation. European Journal of Operational Research, 2018. 267(1): p. 212-226.

19. Salustri, F. Weighted Decision Matrix. 2020 25/07/2020 16/07/2020]; Available from: https://deseng.ryerson.ca/dokuwiki/design:weighted decision matrix.

20. Health and Safety Executive Risk Based Approach Risk Model (Initial Decision Matrix). 2010.
21. Steer and Hastings Borough Council Hastings Seafront Feasbility Mobility Study: Strategic Outline Business Case. 2019. p. 40.

22. Salustri, F. The pairwise comparison method. 2020 12/03/2020 16/07/2020]; Available from: https://deseng.ryerson.ca/dokuwiki/design:pairwise comparison.

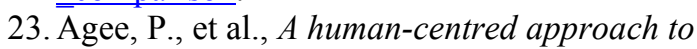
smart housing. Building Research and Information, 2021. 49(1): p. 84-99.

24. Long, F. Real or imaginary: The effectiveness of using personas in product design. in Proceedings of the Irish Ergonomics Society annual conference. 2009. Dublin.

25. Law, P.-M., R.C. Basole, and Y. Wu, Duet: Helping data analysis novices conduct pairwise comparisons by minimal specification. IEEE transactions on visualization and computer graphics, 2018. 25(1): p. 427-437.

26. Turcanu, F.E., et al. Numerical analysis of the thermal comfort in a church building. 2019. EDP Sciences.

27. Varas-Muriel, M.J. and R. Fort, Microclimatic monitoring in an historic church fitted with modern heating: Implications for the preventive conservation of its cultural heritage. Building and Environment, 2018. 145: p. 290-307.

28. Lodi, C., et al., Improvement of thermal comfort and energy efficiency in historical and monumental buildings by means of localized heating based on non-invasive electric radiant panels. Applied Thermal Engineering, 2017. 126: p. 276-289.

29. Samek, L., et al., The impact of electric overhead radiant heating on the indoor environment of historic churches. Journal of Cultural Heritage, 2007. 8(4): p. 361-369.

30. Gwynn, D. and Royal School of Church Music Caring for the king of instruments. 2008.

31. Semprini, G., C. Galli, and S. Farina, Reuse of an ancient church: thermal aspect for integrated solutions. Climamed 2017 - Mediterranean Conference of Hvac Historical Buildings Retrofit in the Mediterranean Area, 2017. 133: p. 327-335.

32. Larsen, P.K. and T. Brostrom, Climate Control in Historic Buildings. 2015, Uppsala University, National Museum of Denmark. 


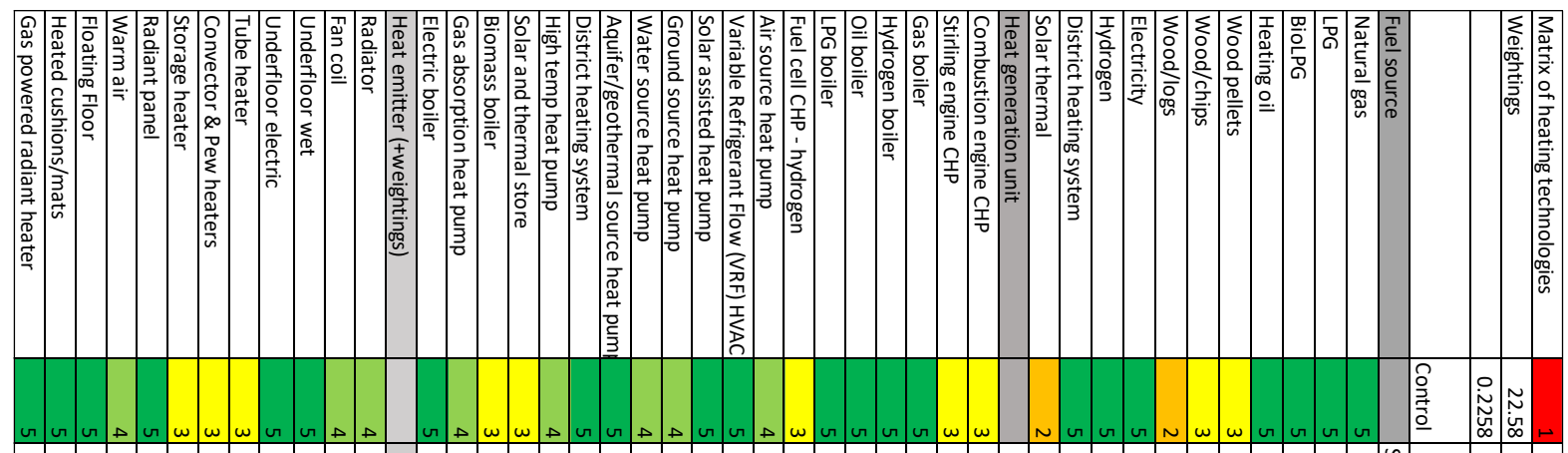

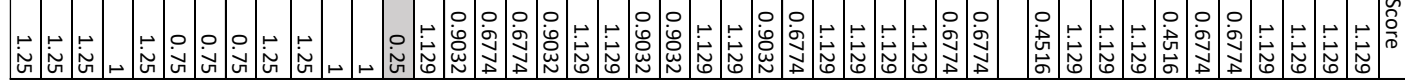

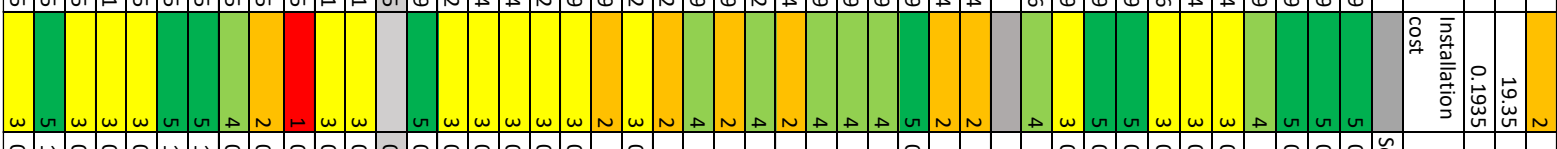

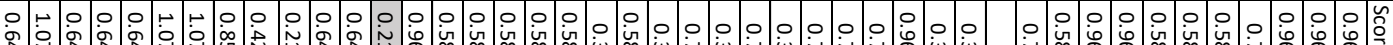

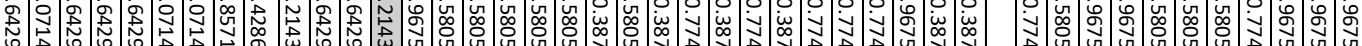

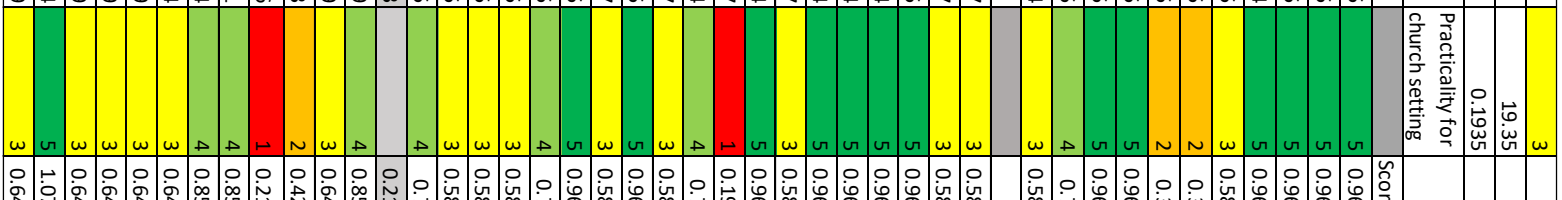

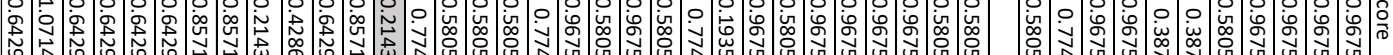

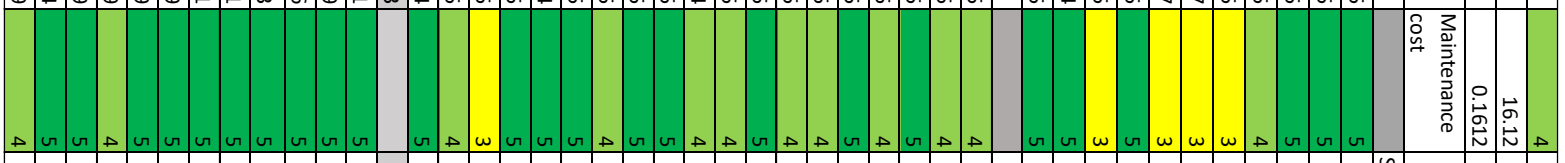

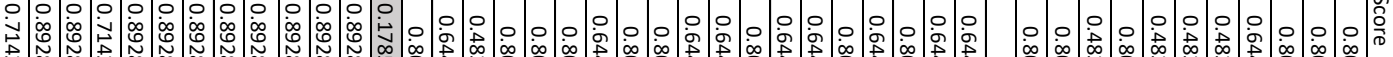

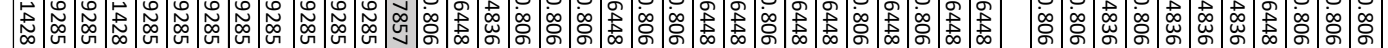

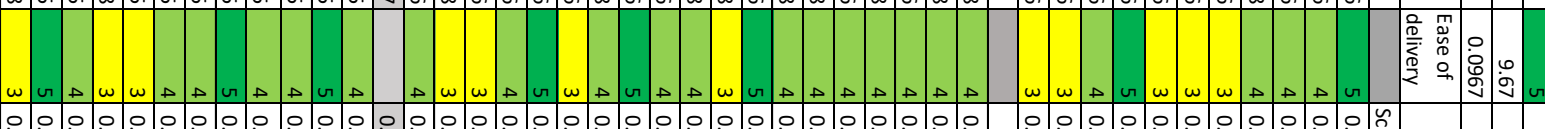

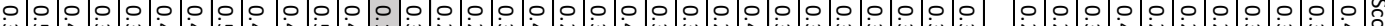

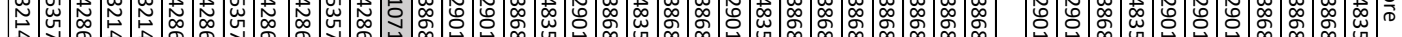

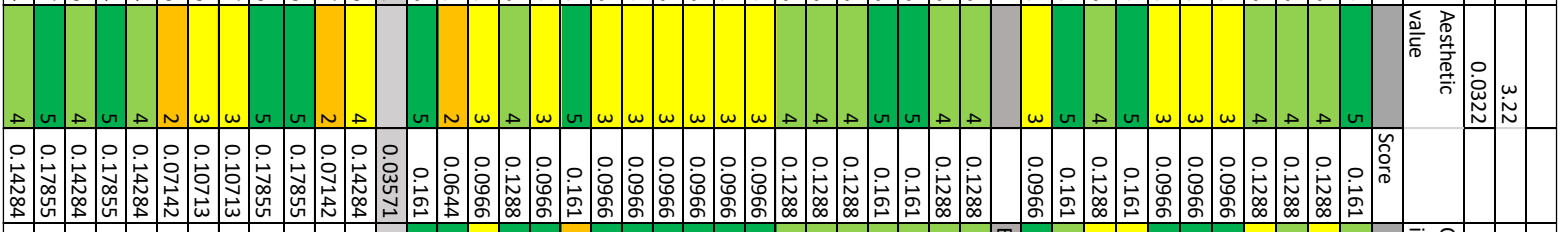

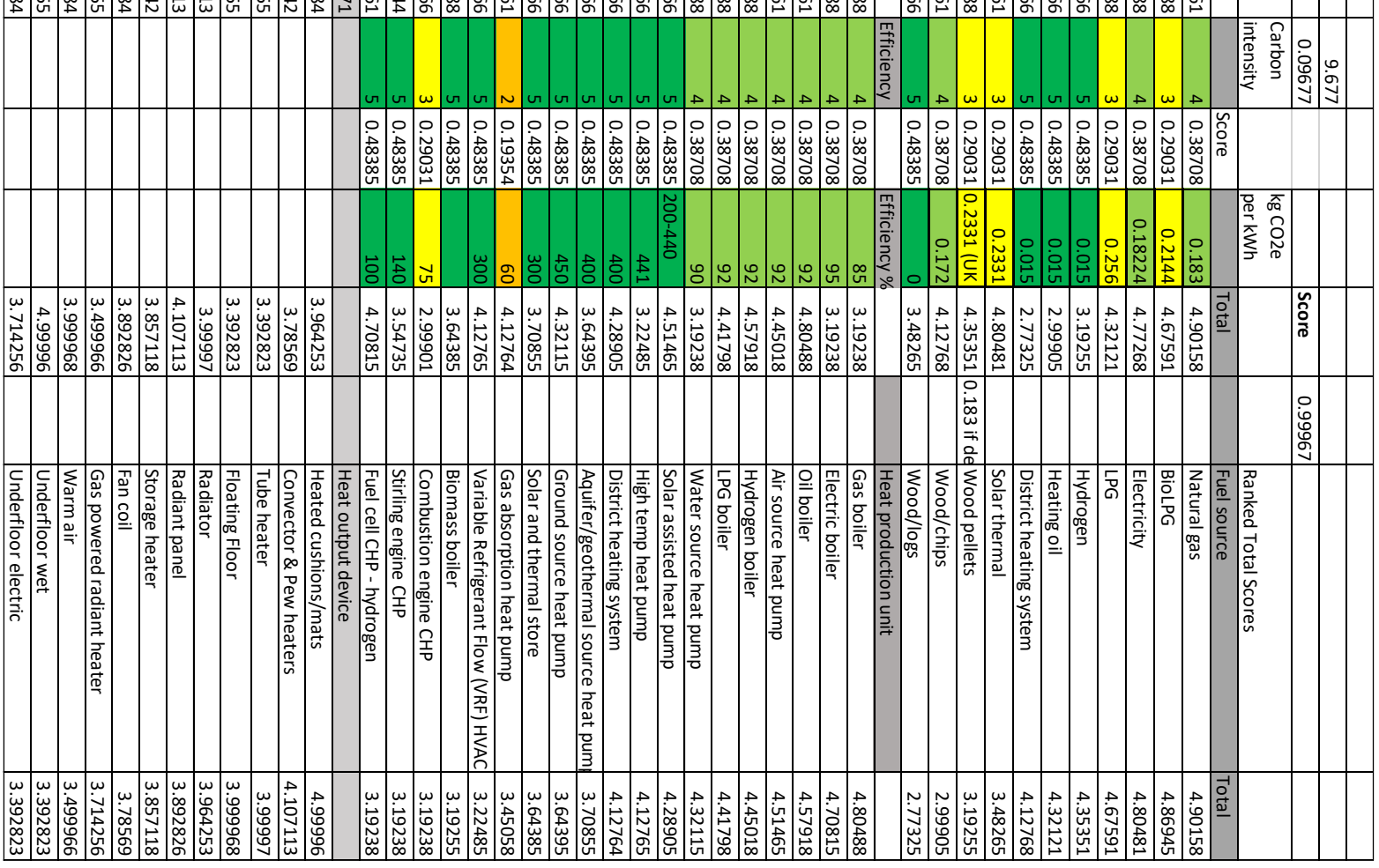

